\title{
The Impact of Electronic Feedback on Second Year English College Students' writing Quality
}

\author{
Wardani Dwi Wihastyanang ${ }^{1}$, M. Adnan Latief ${ }^{2}$ \\ ${ }^{1}$ Student of English Language Teaching Department, State University of Malang, Malang Indonesia \\ ${ }^{2}$ English Language Teaching Department, State University of Malang, Malang Indonesia
}

*Corresponding Author: Wardani Dwi Wihastyanang, Student of English Language Teaching Department, State University of Malang, Malang Indonesia

\begin{abstract}
The aims of this study concerned about the impact of electronic feedback as a new pedagogic practice in EFL learning in general and writing in particular from both students and their lecturers' views. The problem mainly focus on investigating the effectiveness of electronic feedback in the form of learning management system as a pedagogic practice to enhance students' writing quality.

This study adopted quasi experimental methods to investigate the impact of electronic feedback on students' writing quality. A total of 81 English Department students of STKIP PGRI Jombangwere recruited as research participants. They, then, were divided into two groups. The first group, the control group, wasgiven teacher written feedback on their writing drafts while the second group, the experimental group, was given electronic feedback on their writing drafts.The data collection procedure consisted of two types of writing tasks which each participant was asked to write argumentative essays within approximately one hour.The instructor then wrote comments and corrected their work using a red pen after which, the drafts were returned to the class to be rectified before they handed in their final drafts.

The results of this study revealed that written feedback is more effective than electronic feedback. This results were obtained from the mean score of both groups, the experimental and the control groups. The result of the analysis of using t-test revealed that the obtained probability was 0.028 and 0.027. It was higher than significance level $p=0.05$, or statistically there is no significant difference in writing quality of students getting electronic feedback and those getting conventional feedback or teacher written feedback. It means that students who are given electronic feedback have same writing quality than those who are given written feedback.
\end{abstract}

Keywords: Electronic Feedback, EFL Students, Writing Quality

\section{INTRODUCTION}

English, as a foreign language, has become increasingly important to be taught at all school levels in Indonesia. It is indicated from the status of English which remainsthe same until now that English is the first foreign language considered as one of the most substantial elements of education and literacy (Lauder, 2008 as cited by Alwasilah, 2013: 1). The reason to deem English as a paramount foreign language in Indonesia is due to the development of science and technology in the world. Therefore, Indonesia, through its ministry of Education, has seriously responded to the growing needs to foster and strengthen English communication skills of the students (Kemendikbud, 2013).

Regarding with English productive skills,writing is a notable a skill that is necessarily needed by students in this globalized era wheter in their study, life, or employement segments (Craig, 2013 as cited by Amelia 2016: 1). Consequently, students nowdays are demanded to master writing to show their competence in mastering English. Despite, in the fact that writing is very complex due to its process which requires recursiveness and multiple drafting (Amelia, 2016: 1), the previous studies have shown that interest in the area pertaining to writing composition can bring a change in which students become efficient at generating and organizing creative ideas as a result (Nasir, Naqvi \& Bhamani, 2013: 27).

Feedback is viewed as crucial for both encouraging and consolidating learning and this significance has also been recognised in the area of foreign language writing. Amelia (2016: 3) deemed feedback 
as a way of responding to the students' writing. Indeed, feedback is a key component of second language writing programs around the world, by employing product, process and genre approaches a central part of their instructional repertoires (Hyland \& Hyland, 2006: 15). It makes the students see others' responses to their writing and learn from the responses, then get the messages in order to revise their writing to be better at gaining a high quality writing.

The rapid pace at which educational technologies are growing creates a broad spectrum of ways in which technology can be integrated into classroom instruction . Electronic feedback (e-feedback) has drawn researchers' attention and interest (Prins, Slujismans, Kirschner \& Strijbos, 2005; Tuzi, 2004; Chen, 1997; Snyder, 1996) for more than two decades. Electronic feedback is defined as feedback in digital - (described as information, image, audio, video, and etc. that is recorded or broadcast using computer technology) — written form and transmitted via offline or online-transfers the concepts of oral response into the electronic arena (Tuzi, 2004: 217); automatic computer-generated feedback (Chen (1997) \& Snyder (1996), in Allah, 2008: 2) , and electronic assessment of writing (Prins, Slujismans, Kirschner \& Strijbos, 2005 in in Allah, 2008: 2), the results investigation showed that efeedback had a greater impact on revision than oral feedback, in other words, e-feedback might be more useful. In addition, it is claimed that e-feedback helps L2 writers focus on larger writing. Thus, the L2 writer may use e-feedback to create macro revisions.. The focus of this study, however, is the way in which electronic feedback can help not only overcome traditional feedback problems but also, more importantly, improve students' writing quality as well, as the ultimate goal of the writing classroom. In addition, it also investigates the different modes of feedback: teacher/peer feedback and electronic feedback. The rationale behind the sequence of explanation is the movement from nonelectronic feedback to electronic feedback.

Since electronic feedback has more advantages over conventional feedback, why is not there a conclusive result on its effect on students' writing quality? One of the answers to this question is likely as Braine (2001: 288) pointed out, "The students did not make best use of the comments into the revisions". Then how do teachers use electronic response into the revisions? To date, few researchers have answered this question by comparing two modes of peer response in L2 writing (Liu and Sadler, 2003; Schultz, 2000; Huang, 1999). In an attempt to address the question of the impact of electronic feedback on EFL writing, this study explores the impact of electronic feedback and their impact on EFL writing quality. In particular, this study focuses on how is the impact of implementating electronic feedback on EFL Students' writing quality.

The problem of this study focuses on the impact of electronic feedback as a new pedagogic practice in EFL language learning in general and writing in particular from both students and their lecturers' views. The problem investigates the effectiveness of electronic feedback in the form of learning management system as a pedagogic practice to enhance students' writing quality. Therefore, the present study concerns the following research question: Do students who are given electronic feedback have better writing quality than those who are not given electronic feedback?The assumption in this study is "There is a different impact on writing quality between students given electronic feedback and those who are not given electronic feedback". Then, the provisional answer of the research question in this study, called as research hypothesis is "Students who are given electronic feedback have better writing quality than those who are not given electronic feedback". The provisional answer is supported by the previous studies and the current theories have shown that integrating technology into educational programs is effective to enhance students' learning result (Pusack \& Sue, 1997; Scardamalia \& Bereiter, 1991; Urtel, 2008; Wilcox \& Wojnar, 2000). Besides, a study by Guénette (2007) has also confirmed that corrective feedback is effective and influential in improving students' writing.

\section{RESEARCH METHODS}

In order to answer the research questions mentioned, the present study used a quasi-experimental design, particularly posttest only. This design deals with comparing groups through random selection. One group which utilized electronic feedback (X1),is the experiment group and another group, which utilized written feedback (X2), is the control group (Latief, 2012: 96). The feedback is the independent variable (X), while the EFL Students' writing qualityare the dependent variable (Y).

The other consideration why this present study used quasi-experimental design is due to the sample selection. The two groups, both experimental and control groups, because it was possible to select the 
sample randomly (Charles, 1995 in Latief, 2012: 95). Consequently, the researcher selected two groups out of all the existing classes that had equivalent competence, particularly in English writing. The experiment group consisted of two classes (A-B).

The design of the study is illustrated in Table 2.1.

Table2.1. The Control and Experimental condition

\begin{tabular}{|l|l|l|}
\hline \multicolumn{1}{|c|}{ Group } & \multicolumn{1}{|c|}{ Treatment } & \multicolumn{1}{c|}{ Posttest } \\
\hline A & Teacher Written Feedback & Writing Test \\
\hline B & Electronic Feedback & Writing Test \\
\hline
\end{tabular}

Notes:

$A=$ Teacher Written Feedback group (the control group)

$B=$ Electronic Feedback group (the experimental group)

Table 2.1 shows that each group will be measured at the same time with equivalent materials during the treatment. Next, the first control group (A) while used teacher written feedback based on the teacher comment on their essays. The experimental group (B) used teacher electronic feedback on the schoology platform based on the teacher comment on their essays. To collect the data, the post-test will be conducted after the treatment to reveal whether the independent variables really have impact on the dependent variable, the students' writing performance. It will be measured by means of the writing test. The following table depicts the design of this study:

Table2.2 Experimental Design for Experiment and Control Group

\begin{tabular}{|l|l|l|l|l|}
\hline Groups & \multicolumn{3}{|c|}{ Participant Order } \\
\hline Control & $\rightarrow$ & A & $\rightarrow$ & $(\bar{X}) . \mathrm{TWF}$ \\
\hline Experiment & $\rightarrow$ & B & $\rightarrow$ & $(\bar{X}) . \mathrm{EFb}$ \\
\hline
\end{tabular}

\section{Note:}

$A=$ Control Group (A) of writing 3 course

$B=$ Experiment Group 2 of writing 3 course

$(\bar{X}) . E F b=$ Scores obtained from posttest grade using e-feedback

(-).N.EFb $=$ Scores obtained from posttest grade using teacher written feedback

The population in this present study were students of STKIP PGRI Jombang. The researcher considered taking only the students of the second year of English Department who has passed English writing course 1 and writing course 2. During the implementation of the research, the research subjects were in the middle of finishing writing course 3 . The writing course 3 was divided into two classes: Class A with 47 students as the control group and Class B with 34 students as the experimental group, altogether were 81 students second year English majors, all the students' language proficiency ranged from GPA beyond 2,75 based on the end of the third semester and, which means the GPA were obtained, while the students were finishing Writing course 2.

There were two groups of participants for this experimental study. The first group, the control group, wasgiven teacher written feedback on their writing drafts while the second group, the experimental group, was given electronic feedback on their writing drafts. The data collection procedure consisted of two types of writing tasksand each participant was asked to write argumentative essays within approximately one hour.This study used two research instruments namely, writing test (WT) and questionnaire. Writing test is use to analyze the impact of electronic feedback based on students writing score. Questionnaire is use to know the students' respon for the implementation of electronic feedback.The procedure of data analysis of the this study were undertaken the following order: Scoring, Tabulation, Descriptive Statistical Analysis, Fullfilment Statistical Assumptions, Statistical Hypothesis and Its Testing, Criteria of Acceptance, of The Statistical Hypothesis and Procedures of Testing The Hypothesis.

\section{FINDINGS}

The present study tried to investigate whether there was a difference impacton writing quality between students given electronic feedback and students given written feedback. It was aimed to answer the research question: "Do students who are given electronic feedback have better writing quality than those who are not given electronic feedback?". To answer and investigate the different impact on students' writing quality, the comparison of the mean scores of experimental group and control group and the Independent Sample t-test are presented further below. 
All students listed in the attendance list in the experimental $(n=32)$, the control $(n=38)$, groups were involved to join the posttest in this study. The result of scoring all the students' essay can be seen inAppendix $5 \mathrm{~b}$ for the control group and Appendix $5 \mathrm{c}$ for the experiment group. To give more vivid picture of the result of the post-test, the scores are illustrated in the form of the histogram on Figure 3.1 .

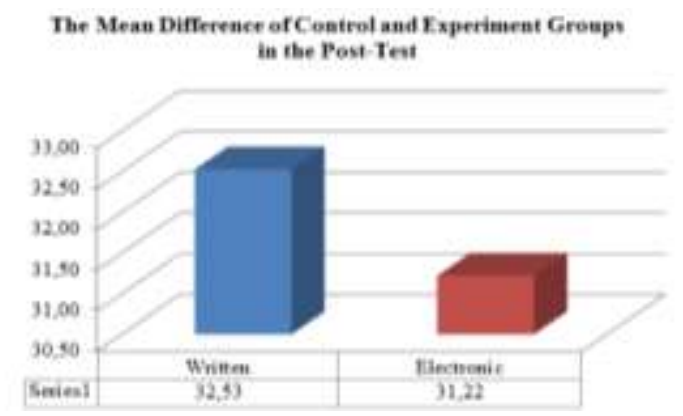

Figure.3.1 The Mean Difference of Control and Experiment Groups in the Post-Test

The descriptive statistical analysis results of both the written feedback group and the electronic feedback group are displayed in this sub-chapter in one section in order to see the different results from both groups. Besides, it is also important to see the results before coming to the hypothesis in this study. Table 3.2 on the next page displays the summary of the posttest results.

Table3.1 The Descriptive Statistical Analysis of the Posttest in the Control and the Experimental Groups

\begin{tabular}{|c|c|c|c|c|c|}
\hline \multicolumn{7}{|c|}{ Descriptive Statistics } \\
\hline Feedback & N & Minimum & Maximum & Mean & Std. Deviation \\
\hline Written & 38 & 29 & 37 & 32,53 & 2,544 \\
\hline Electronic & 32 & 28 & 37 & 31,22 & 2,296 \\
\hline Valid N (listwise) & 32 & & & & \\
\hline
\end{tabular}

Table 3.1 shows that the means between written groups and electronic groups are statistically different. The findings show that the mean score for written groups is 32,53 , which is higher than, the mean score of electronic group which is only 31,22 .

The next step after doing all the test was the hypothesis testing. It was used to verify whether or not the null hypothesis was rejected. Referring to the mean of written feedback and electronic feedback, it could be revealed that the mean of written feedback is higher than that of electronic feedback. Then according to the basis of decision making in the Independent Sample t-test, Ho is rejected. See Table 3.8to know the summary of the Independent Samples T-Test of the Written Feedback Group and the Electronic Feedback Group.

Table 3.8 Comparison of Writing Quality of the Written Feedback Group and the Electronic Feedback Group

\begin{tabular}{|c|c|c|c|c|c|}
\hline \multicolumn{6}{|c|}{ Independent Samples Test } \\
\hline & & \multicolumn{2}{|c|}{ Levene's Test for Equality of Variances } & \multicolumn{2}{|c|}{ t-test for Equality of Means } \\
\hline & & $\mathrm{F}$ & Sig. & $\mathrm{t}$ & $\mathrm{df}$ \\
\hline \multirow[t]{2}{*}{ Nilai } & Equal variances assumed & 2,690 & , 106 & 2,239 & 68 \\
\hline & Equal variances not assumed & & & 2,259 & 67,649 \\
\hline \multicolumn{6}{|c|}{ Independent Samples Test } \\
\hline & & \multicolumn{4}{|c|}{ t-test for Equality of Means } \\
\hline & & Sig. (2-tailed) & Mean Difference & Std. & Difference \\
\hline \multirow[t]{2}{*}{ Nilai } & Equal variances assumed &, 028 & 1,308 & & 84 \\
\hline & Equal variances not assumed &, 027 & 1,308 & & 79 \\
\hline
\end{tabular}

Based on the output, of the independent sample t-test, the results can be drawn as follows: (1) The probability (the value of Sig. (2-tailed)) that the difference is due to chance is .028 and .027 , (2) Since the probability that the difference is due to chance is higher than 0.05 , there is no significant difference between written feedback and electronic feedback, (3) The difference between written feedback and electronic feedback is not significant. The result of the analysis of using t-test revealed that the obtained probability was 0.028 and 0.027 . It was higher than significance level $p=0.05$, it meant that statistically there is no significant difference in writing quality of students getting electronic feedback and those getting conventional feedback or teacher written feedback. 


\section{DISCUSSION}

The focus of this study was investigating the impact of electronic feedback and written feedback on students' writing quality. Therefore, there were two groups involved in this study, they were electronic feedback group which functioned as the experimental group and the written feedback group which functioned as the control group. Chapter III showed the statistical analysis which by using ttest. The results of the statistical analysis, then, become the empirical evidence related to this study.

Referring tothe results of multiple comparisions (ANOVA) of writing aspect in both teacher written feedback and electronic feedback in Chapter III, this study revealed that the result was all of the three writing aspect have significant differences, but the dominant writing aspect in influencing the students' score was content aspect. In relation to the content components of the writing, the students' writing ability is scored based on their competency of the topic development. In other words, students need to show their ability to critically provide adequate information for developing the topic of their writing task. Unfortunately, the students could not be able to develop the content of their writing critically. It is advised that students need to work hard to generate ideas from various sources in order to make their writing clear and free of slang. The quality of writing can be defined as the wellorganized writing containing well-developed ideas and clear detail (Needels\& Knapp, 1994). Writing quality was considered as the main important output of writing and learning (Bangert-Drowns, 1993; Goldberg et al., 2003; Graham, 2006; Graham \& Harris, 2003; Hillocks, 1986). In other words, writing quality and the accuracy of the writing content need to be measured as it can be resulted in writing performance

Writing ability needs to be clearly developed by avoiding ambiguous ideas and eliminating unnecessary words in order to make a reader easy to follow. It means that a writer needs to follow the process of writing namely planning, evaluating, and revising. So, the writing develops a good productive draft by considering its unity and coherence. At the last stage, writing product acts as tool for transferring one's own ideas, experience and knowledge (Bereiter, 1980). Having become more advanced writers, students change their writing performance gradually from "knowledge-telling" to "knowledge-transformation" (Bereiter\&Scardamalia, 1987, pp. 5-6).

Knowledge telling means the writing ability of the students is still low although they include the content of their writing. In contrast, knowledge transformation means the students are at more advanced level writers whose ability is used to develop more complex ideas, reasoning, knowledge, philosophical awareness and personal ideas.Referring to the results of the statistical analysis, this study revealed that written feedback is more effective than electronic feedback. This results obtained from the mean score of both groups, experimental and control group. The mean score of control group was 32 , which is higher than, the mean score of experimental group which was only 31 ,. In other words, the theoretical hypothesis is rejected, then, the statistical hypothesis of this study (H0) is rejected. It also signified that the students who were given written feedback had better writing quality than the students who were given electronic feedback.

These results were actually a bit surprising since they were different from the results of the pilot study. However, it is rational since most students who were given electronic feedback did plagiarism by copying other source in the internet in their writing. It was one of the disadvantages of applying electronic feedback to the finding in this study. In short, the core factor influenced the bad results of students' writing quality was plagiarism. The copy-paste culture seems to be a common secret among students. Through the easy access to information, it is not a difficult thing to get the material or reference to complete academic tasks. If this continues then it will further enhance the culture of plagiarism. In fact, not a few academics are caught in plagiarism cases. This is one of the negative impacts of technological sophistication because it is not used in accordance with the appropriate manners. Sommers and Sattel (2005 as cited by Strom: 2007; in Hartanto, 2012: 5) suggested that cheating occurs because of behavioral erosion, where students are more concerned with helping their friends in the work and exams. It can also make students accustomed to lying because they are more likely to help a friend in the exam.

Seliem \& Ahmed (2009) stated that electronic feedback is proved to be essential in the teaching and learning of essay writin, however, it also produces some disadvantages which gives impact to students' writing results. In addition Allah (2008) also explained that the use of computer and internet in writing class produces a problem like students who are not familiar with electronic feedback are more likely to find the practice difficult and time consuming. Those two reasons above may become 
the core influence on why the students in the experimental group was not better than the control group in this study.

Furthermore, Hyland \& Hyland (2006), contended that written feedback from lecturers still plays a central role in most ESL and EFL writing classes. Another issue raised in the written feedback literature is the extent to which students can understand and use written feedback provided by their lecturers. Leki (1992) emphasized that the written feedback is processed by supporting the author through several concepts of proposed revisions during the writing process rather than the final process. This has a significant effect on finding ideas against revision practices from written feedback. Important for this view is the belief that teacher feedback is most effective when delivered at the intermediate stage of the writing process when students have the opportunity to incorporate the idea of written feedback results into their text. Ellis (2009) mentioned that this is a teacher's strategy to improve their students' surface level errors. Some empirical studies of written feedback produce a term called 'optional typology to correct linguistic errors'. This typology is done by the lecturer by providing direct, indirect or metalinguistic corrective feedback. In theory, written feedback involves teachers identifying linguistic errors and giving students the right idea. In other words it only requires an indication that there is a mistake, from the written feedback the focus of student attention can be drawn to the error by finding errors and revising the writing.

Some facts mentioned that many lecturers are not satisfied unless they have written substantial feedback about their students' papers. In addition, the results of a survey conducted by Leki, 1991, Saito, 1994, suggested that feedback written by lecturers is also highly appreciated by students (Hyland, F, 1998) and became popular.In this study, it was found out that written feedback in the form of comments from lecturers is very effective in improving the quality of students' writing. In the findings of this study, it was found out that the lecturers' tendency to use comments are not understood by the students. The ability of lecturers and students 'ability in responding to comments in electronic feedback becomes a factor that is very influential in the quality of revision results of students' argumentative writing. Correspondingly, Cohen \& Cavalcanti (1990), for example, found out that the nature of comment differs by proficiency. For example, the case of low-level learners who received some comments about vocabulary or content. The lecturer chose instead to concentrate his comments on grammar and mechanics.

In order to investigate the reason for non-significant effect of e-feedback, this study used the students' perception of using schoology as e-feedback in their writing classes, end-of-semester questionnaires were analyzed. Descriptive statistics were computed to calculate the mean scores and percentage of the items in the questionnaire. The result of the student's responses to the implementation of electronic feedback using Schoology was done through a questionnaire analysis which has filled 26 students of experimental class at the last meeting of the research. The results of questionnaire responses data analysis students can be seen in Table 3.9.

Table 3.9 The Average of Questionnaire Responses

\begin{tabular}{|c|c|c|c|}
\hline No & Questions & Average & Criteria \\
\hline 1. & Q1. I know and understand the schoology as e-feedback? & 3,81 & Agree \\
\hline 2. & Q2. I like the schoology learning media as e-feedback? & 3,88 & Agree \\
\hline 3. & Q3. Schoology as e-feedback is an appropriate learning media to be applied & 3,92 & Agree \\
\hline 4. & Q4. I do not find any difficulties to use Schoology as e-feedback? & 3,69 & Agree \\
\hline 5. & Q5. I just love reading the material and doing the evaluation in Schoology as e-feedback & 3,62 & Agree \\
\hline \multicolumn{1}{|c|}{ Average } & 3,78 & Agree \\
\hline 6. & Q6. Lecturers provide materials by including material resources in Schoology as e- \\
feedback & 3,81 & Agree \\
\hline 7. & Q7. Learning without face-to-face in Schoology as e-feedback is good & 3,38 & Simply Agree \\
\hline 8. & Q8. Lecturers utilize facilities that support the learning of Schoology as e-feedback & 3,77 & Agree \\
\hline 9. & Q9. lecturers fairly assess the students in the learning of Schoology as e-feedback & 3,85 & Agree \\
\hline 10. & Q10. I use facilities that support Schoology learning as e-feedback & 3,81 & Agree \\
\hline 11. & Q11. Schoology learning as e-feedback is more fun than conventional one (lecturing) & 3,69 & Agree \\
\hline 12. & Q12. The campus facility has supported the learning of Schoology as e-feedback & 3,46 & Simply Agree \\
\hline \multicolumn{2}{|c|}{ Average } & $\mathbf{3 , 7 2}$ & Agree \\
\hline 13. & Q13. Do you have any obstacles in applying Schoology as e-feedback? If any,please mention the obstacles and give \\
\hline 14. & Q14. What do you think about the implementation of Schoology as e-feedback at campus? \\
\hline 15. & Q15. What are the advantages and disadvantages of Schoology implementation as e-feedback in campus? \\
\hline
\end{tabular}


Simillarly, the students' responses for Q6 to Q12 related to Schoology features, were average, score 3,72. The students' responses for Q6, related to including material resources on e-feedback implementation, were average, score 3,81.It indicated that lecture can provide material on schoology. The students' responses for Q7, related to the schoology as e-feedback quality, were average, score 3,38.It indicatedthe students perceived that the schoology as e-feedback has an average quality. The students' responses for Q8 and Q10, related to the supporting facilities of schoology as e-feedback quality, were average, score 3,77 and 3,81.It indicated that the schoology as e-feedback have the supporting facilities that can used for learning media. The students' responses for Q9, related to assessment facilities of the schoology as e-feedback, were average, score 3,85.It indicatedthe students perceived that the schoology as e-feedback can be used as evaluation tool. The students' responses for Q11, related to the students' experience in the implementation of schoology as an e-feedback compared with the conventional method (lectures), were average, score 3,69. It indicated that the implementation schoology as learning media was interesting. The students' responses for Q12, related to the campus facilities, were average 3,46. It indicated that the campus facilities that supported efeedback were lack of facilities. However, the average scores for Q7 and Q12 was 3. It revealed that students percievede-feedback through Schoology is seen as a learning activity which they neither agree nor disagree.

Dealing with quality (Q7), most of students perceived that the quality of schoology should be adjusted to the learning process that is implemented. It meant that there are some facilities in the schoology that must be appropriated to the students' learning styles. Furthermore, dealing with campus facilities (Q12) that supported the e-feedback implementation, most of the students' percieved that campus facilities need to be upgraded to support the e-feedback requirements.

Dealing with non-significant effect of e-feedback, there were three questions that can be potrayed the problems in the e-feedback implementation. First, Q13, related to the obstruction of e-feedback implementation, there were negative responses from the students that can be seen in the Table 3.6.

Table3.10 The Students' Negative Responses on Obstacles (Question 13)

\begin{tabular}{|c|c|}
\hline Factors & Students' Negative Response \\
\hline $\begin{array}{l}\text { Teaching } \\
\text { Learning Process }\end{array}$ & $\begin{array}{l}\text { 1. Learning seems to be no direct practice guided by a lecturer } \\
\text { 2. The constraints that occur are not all learning using computer effective. Many lessons are } \\
\text { more effective through cooperative and collaborative learning. } \\
\text { 3. The problem is that there is no face to face learning and it is difficult to understand } \\
\text { lessons without explanations } \\
\text { 4. It is important to socialize schoology learning media to make students understand }\end{array}$ \\
\hline $\begin{array}{l}\text { es and } \\
\text { ire }\end{array}$ & $\begin{array}{l}\text { 1. Available, Lack of facility hampers the implementation of e-learning process. } \\
\text { 2. Another challenge is that the availability and feasibility of E-learning infrastructure itself. } \\
\text { In reality, not all schools have the facilities to run E-learning as well as in Higher } \\
\text { Education not all facilities are eligible to be used for the learning process of E-learning. } \\
\text { 3. The Internet signals are sometimes too bad } \\
\text { 4. Available, the Internet network facilities are still not adequate } \\
\text { 5. Internet network facilities are still not adequate } \\
\text { 6. Yes, because sometimes if the system of schoology is in error we cannot access and apply } \\
\text { the app properly } \\
\text { 7. Available, because network constraint and its web is hard to access } \\
\text { 8. Available. Due to the network constraints. }\end{array}$ \\
\hline
\end{tabular}

From Table 3.6that presents the students' response, it can be concluded that the main problem was lack of infrastructure and the limitation of Internet access. For example, students' response no. 1 stated that "Available, Lack of facility hampers the implementation of e-learning process" and students' no. 3 stated "The Internet signals are sometimes too bad"

Second, Q14, related to the implementation of e-feedback implementation, there were also negative responses from the students that can be seen in Table 3.11.

From Table 3.7, it can be concluded that Schoology as e-feedback is good if the facilities and infrastructure were adequate and always connected to the internet. For example, students' response no. 1 stated that "Not yet adequate because the education system uses electronic applications to support teaching and learning with the media of the Internet, computer network, and computer 
standalone. The three components are expected to be fulfilled so that the E-learning learning run interactively" and students' no. 2 stated "Agree. As long as the facilities are adequate.

Table3.11 The Students' Perception on the Implementation (Question 14)

\begin{tabular}{|c|c|}
\hline Factors & Students' Negative Response \\
\hline $\begin{array}{l}\text { Teaching } \\
\text { Learning } \\
\text { Process }\end{array}$ & $\begin{array}{l}\text { 1. Still to be reviewed } \\
\text { 2. Still practically less implemented properly } \\
\text { 3. Good, but not can not avoid conventional learning with face-to-face learningbecause the } \\
\text { direct interaction between lecturers and students is also very important. } \\
\text { 4. Quite good, maybe it can be improved again so as not to be left behind with other state } \\
\text { universities / private universities. }\end{array}$ \\
\hline \begin{tabular}{|l|} 
The \\
facilities and \\
infrastructur \\
e
\end{tabular} & $\begin{array}{l}\text { 1. Not yet adequate because the education system uses electronic applications to support } \\
\text { teaching and learning with the media of the Internet, computer network, and computer } \\
\text { standalone. The three components are expected to be fulfilled so that the E-learning } \\
\text { learning run interactively } \\
\text { 2. Agree. As long as the facilities are adequate. } \\
\text { 3. Agreed, if the facilities and infrastructure are available and can support teaching and } \\
\text { learning activities } \\
\text { 4. Schoology is good if facilities and infrastructuresupport PC devices and is always connected } \\
\text { to the internet }\end{array}$ \\
\hline
\end{tabular}

Third, Q15, related to the advantages and disadvatages of e-feedback, the students response can be seen on the table 3.12

Table3.12 The Students' Responses on Advantages and Disadvatages (Question 15)

\begin{tabular}{|c|c|}
\hline Factors & Students' Negative Response \\
\hline Advantages & $\begin{array}{l}\text { 1. We can be anywhere, can learn anytime. } \\
\text { 2. Faster access to information. } \\
\text { 3. Lecturers and students can use structured and scheduled teaching materials via the } \\
\text { internet. } \\
\text { 4. Students can learn (review) teaching materials at anytime and anywhere if necessary as } \\
\text { the materials are stored in the computer. } \\
\text { 5. If the student requires additional information relating to the material he / she studies, he } \\
\text { / she can access the internet. } \\
\text { 6. Both teachers and students can conduct discussions through the internet that can be } \\
\text { followed by a large number of participants. } \\
\text { 7. The changing role of the student from the passive becomes active. } \\
\text { 8. Relatively more efficient } \\
\text { 9. Time is more flexible, so that under certain conditions where lecturers and students are } \\
\text { not able to meet directly, the learning process can run }\end{array}$ \\
\hline Disadvantages & $\begin{array}{l}\text { 1. if there is no internet connection and less suitable material } \\
\text { 2. If a student is less able to master the technology will hinder the process of e-learning } \\
\text { 3. Lack of interaction between teachers and students or even among students themselves, } \\
\text { can slow the formation of values in the learning process. } \\
\text { 4. The tendency to ignore the academic or social aspects and vice versa encourage the } \\
\text { business or commercial aspects. } \\
\text { 5. The learning and teaching process tends toward training rather than education. } \\
\text { 6. Changing the role of teachers from the master of conventional learning techniques to the } \\
\text { master of the ICT learning techniques } \\
\text { 7. If the system is error because of overloaded use, it luckily still can be accessed by } \\
\text { anyone. } \\
\text { 8. Maybe only lack of socialization } \\
\text { 9. Less familiar with the materials } \\
\text { 10. A fast internet network is required }\end{array}$ \\
\hline
\end{tabular}

From Table 3.12that presents the students' response based on the students' experience, there were some advantages about accessibility and timeliness, For example, students' response no. 1 stated that "We can be anywhere, can learn anytime" and students' no. 4 stated "Students can learn (review) teaching materials at anytime and anywhere if necessary as the materials are stored in the computer." Furthemore, students' response no. 9 stated "Time is more flexible, so that under certain conditions where lecturers and students are not able to meet directly, the learning process can run". 
While, the disadvantages based on the students' experience were about facilities and infrastructure. For example, students' response no. 1 stated that "if there is no internet connection and less suitable material" and students' no. 2 stated "If a student is less able to master the technology will hinder the process of e-learning". It can be concluded that the most influential factors of e-feedback implementation are due lack of facilities and infrastructure. The use of electronic devices such as smartphones, computers or laptops can be one of the factors that inhibit the use of electronic feedback.

\section{CONCLUSSION}

Based on the research problems and the results of data analysis, a number of conclusions are drawn. The first conclusion is that there is no significant difference between students given electronic feedback and those who are not given electronic feedback. It meant that the results of the study may be assumed that the students' writing quality was improved when the lecturer provides feedback by using written feedback with a clear comment to improve the quality of the revised draft.

Due to the non-significant difference, some reason are put forward. First, dealing with quality, it concludes that schoology as e-feedback has an average good quality, depending on the infrastructure and the Internet access.

Second, dealing with disadvantages, it meant that Schoology as e-feedback is good if the facilities and infrastructure were adequate and always connected to the internet. Third, dealing with students' negative response of the e-feedback implementation, there are some advantages about accessibility and timeliness and disadvantages of facilities and infrastructure. It can be concluded that the most influential factors of e-feedback implementation are due to lack of facilities and infrastructure. Some students argue that the ineffectiveness of e-learning might be caused by the differences of students' learning style and the first thing to do before the implementation of e-feedback is to provide good facilities and infrastructure.

\section{REFERENCES}

[1] Allah, L. F. (2008). Electronic Feedback: Is It Beneficial for Second Language Writers? Cairo, Egypt: The American University in Cairo.

[2] Allwaright, R. (1975). Probelms in the Study of Language Teacher's Treatment of Error. TESOL Quarterly.

[3] Alsied, S. M., \& Pathan, M. M. (2013). The Use of Computer Technology in EFL Classroom: Advantages and Implications. International Journal of English Language \& Translation Studies, 44-51.

[4] Alwasilah, A. C. (2013). Policy on Foreign Language Education in Indonesia. International Journal of Education, 1-19.

[5] Ashwell, T. (2000). Patterns of Teacher Response to Student Writing in a Muliple-Draft Composition Classroom: Is Content Feedback Followed by Form Feedback the Best Method? Journal of Second Language Writing, 227-257.

[6] Balmeo, M. L., Nimo, E. M., Pagal, A. M., Puga, S. C., Quino, A. D., \& Sanwen, J. L. (2014). Integrating Technology in Teaching Students with Special Learning Needs in the SPED Schools in Baguio City. The IAFOR Journal of Education, 149-178.

[7] Bitchener, J. (2008). Evidence in Support of Written Corrective Feedback. Journal of Second Language Writing, 102-118.

[8] Brandl, K. (2002). Integrating Internet Based Reading Materials into the Foreign Language Curriculum: from Teacher to Student Centered Approaches. Languge Learning \& Technology, 87-107.

[9] Brown, H. D., \& Lee, H. (2015). Teaching by Principles: An Interactive Approach to Language Pedagogy (5th Edition). New York: Pearson Education.

[10] Cardelle, J., \& Corno, L. (1981). Effects of Second Language Learning of Variations in Written Feedback on Homework Assigments. TESOL Quarterly, 251-261.

[11] Carless, D. (2006). Differing Perceptions in the Feedback Process. Studies in Higher Education, 219-233.

[12] Cavkaytar, S., \& Yasar, S. (2010). Using Writing Process in Teaching Composistion Skills: an Action Research. International Conference ICT for Language Learning 3rd Edition (hal. 1-7). Florence: Liberia Universitia.

[13] Chen, J. (1997). Computer Generated Error Feedback and Writing Process. TESL_EJ.

[14] Cole, J., \& Foster, H. (2007). Using Moodle, 2nd Edition. Sebastopol, CA: O'Reilly Media, Inc.

[15] Conrad, S. M., \& Goldstein, L. (1999). Student Revision After Teacher Written Comments: Text, Context and Individuals. Journal of Second Language Writing, 147-180.

[16] Dawn, K., \& Oberman, D. A. (2001). Improving Student Writing Skills through the Modeling of the Writing Process. Chicago, Illinois: Saint Xavier University \& IRI/Skylight. 
[17] Diaz, L. A., \& Entonado, F. B. (2009). Are the Functions of Teachers in e-Learning and Face-to-Face Learning Environements Really Different? Educational Technology \& Society, 331-343.

[18] Driscoll, M. P. (2007). Psychology Foundation of Instructional Design. Trends and Issues in Instructional Design and Technology, 36-44.

[19] Duomont, J. (2002). A Teaching Tip. Online Publishing: http://iteslj.org/Techniques/DuomontFeedback.html.

[20] Ellis, R., Loewen, S., \& Erlam, R. (2006). Implicit and Explicit Corrective Feedback and the Acquisiion of L2 Grammar. Studies in Second Language Acquisition, 339-368.

[21] Ferris, D. (1997). The Influence of Teacher Commentary on Student Revision. TESOL Quarterly, 315336.

[22] Ferris, D. (1999). The Case for Grammar Correction in L2 Writing Classes: A Response to Truscott. Journal of Second Language Writing, 1-10.

[23] Ferris, D. R., \& Hedgcock, J. s. (2011). Teaching ESL Composition: Purpose, Process, and Practice. New York: Routledge.

[24] Ferris, D., \& Roberts, B. (2001). Error Feedback in L2 Writing Classes: How Explicit Does It Need To Be? Journal of Second Language Writing, 161-184.

[25] Frantzen, D. (1995). The Effects of Grammar Suplementation on Written Accuracy in An Intermediate Spanish Content Course. Modern Language Journal, 329-344.

[26] Grabe, W., \& Kaplan, R. B. (1996). Theory and Practice of Writing: An Applied Linguistic Perspective. United Kingdom: Longman.

[27] Grabe, W., \& Kaplan, R. B. (1996). Theory and Practice of Writing: An Applied Linguistics Perspective. London: Longman.

[28] Guenette, D. (2007). Is Feedback Pedagogically Correct? Research Design Issues in Studies of Feedback on Writing. Elsevier, 40-53.

[29] Hedge, T. (2000). Teaching and Learning in the Language Classroom. United Kingdom: Oxford University Press.

[30] Huang, S.-y. (1999). EFL Students' Use of Ideas Provided by Peers During Prewriting Discussions Conducted on Network Computers. Taiwan: Tunghai University.

[31] Hyland, F. (1998). The Impact of Teacher Written Feedback on Individual Writers. Journal of Second Language Writing, 255-286.

[32] Hyland, K. (2003). Second Language Writing. Cambridge: Cambridge University Press.

[33] Hyland, K., \& Heyland, F. (2006). Feedback on Second Language Students' Writing. Hong Kong: The University of Hong Kong.

[34] J., C. (2003). The Efficacy of Various Kinds of Error Feedback for Improvement in the Accuracy and Fluency of L2 Student Writing. Journal of Second Language Writing, 267-296.

[35] Kapka, D., \& Oberman, D. A. (2001). Improving Student Writing Skills through the Modeling of the Writing Process. United State: Saint Xavier University and SKyLight Professional Development FieldBased Masters.

[36] KEMDIKBUD. (2013). Peraturan Menteri Pendidikan dan Kebudayaan Republik Indonesia. Jakarta: Kemdikbud.

[37] Kern, R. (2006). Perspective on Technology in Learning and Teaching Languages. TESOL Quarterly, 183 210.

[38] Kheradmand, N., \& Sayadiyan, S. (2016). Comparative Investigation of the Effects of Immediate and Delayed Error Correction on the Achievement of Male and Female Iranian EFL Learners' Writing Skill. International Journal Social Science \& Education, 31-39.

[39] Kitchakarn, O. (2013). Peer Feedback through Blogs: An Effective Tool for Improving Students' Writing Abilities. Online Journal of Distance Education, 152-164.

[40] Kolb, A. Y., \& Kolb, D. A. (2008). Experiental Learning Theory: A Dynamic, Holistic Approach to Management Learning, Education and Develpment. Sage, 1-59.

[41] Kulhavy, R. W. (1977). Feedback in Written Instruction. Review of Educational Research, 211-232.

[42] Latief, M. A. (2012). Research Methods on Language Learning An Introduction. Malang: UM Press.

[43] Lauder, A. (2008). Makara. Sosial Humaniora, 9-20.

[44] Lehr, F. (1995). Revision in the Writing Process. ERIC, 16.

[45] Liu, J., \& Hansen, J. (2002). Peer Response in Second Language Writing Classroom. Michigan: The University of Michigan Press.

[46] Liu, J., \& Sadler, W. R. (2003). The Effect and Effect of Peer Review in Electronic versus Traditional Modes on L2 Writing. Journal of English for Academic Purposes, 193-227.

[47] Motteram, G. (2013). Innovations in Learning Technologies for English Language Teaching. London: Spring Gardens.

[48] Nasir, L., Naqvi, S. M., \& Bhamani, S. (2013). Enhancing Students' Creative Writing Skills: An Action Research Project. Acta Didactica Napocensia, 27-32. 
[49] Nasir, M., Shakeel, M., Wahid, N., \& Palwasha, A. (2015). Effect of Direct and Indirect Feedback on Urdu EFL Learners at Graduation Level. Journal of Policy Research, 72-87.

[50] Prins, F., Sluijsmans, D., Kirschner, P., \& Strijbos, J. (2005). Formative Peer Assessment in a CSCL Environment: A Case Study. Assessment \& Evaluation in Higher Education, 417-444.

[51] Pusack, J. P., \& Sue, O. K. (1997). Taking Control of Multimedia. Lincolnwood: National Textbook Company.

[52] Robb, T. N. (1997). The Paperless Classroom? TESL-EJ.

[53] Robb, T., Ross, S., \& Shortseed, I. (1986). Salience of Feedback on Error and Its Effect on EFL Writing Quality. TESOL Quarterly, 83-95.

[54] Sahan, O. (2012). The Effectiveness of Writing and Oral Feedback on EFL Writing Performance. Erzurum: Ataturk University.

[55] Scardamalia, M., \& Bereiter, C. (1994). Computer Support for Knowledge-Building Communities. The Journal of the Learning Science, 265-283.

[56] Schultz, J. (2000). Computers and Collaborative Writing in the Foreign Language Curriculum. Cambridge: Cambridge University Press.

[57] Schwartz, F., \& White, K. (2000). Making Sense of It All: Giving and Getting Online Course Feedback. The Online Teaching Guide, 167-182.

[58] Semke, H. D. (1984). Effect of the Red Pen. Foreign Language Annals, 194-202.

[59] Sheen, Y. (2007). The Effect of Focused Written Corrective Feedback and Language Aptitude on ESL Learners' Acquisition of Articles. TESOL Quarterly, 255-283.

[60] Silva, T. (1987). ESL Composition: An Historical Perspective. CCCC Annual Convention (hal. 1-11). Atlanta: The Educational Resources Information Center (ERIC).

[61] Smith, C. B. (2000). Writing Instruction: Current Practices in the Classroom. ERIC Digests, 1-6.

[62] Snyder, M. (1996). The Paperless Writing Course: A Relevant Business Writing Course. ERIC.

[63] Stevenson, M., \& Phakiti, A. (2014). The Effects of Computer-Generated Feedback on the Quality of Writing. Elsevier, 51-65.

[64] Sulistyo, G. H. (2015). Assessment at Schools. Malang: CV. Bintang Sejahtera.

[65] Tompkins, G. E. (2004). Teaching Writing: Balancing Product and Process. Upper Saddle River: NJ: Merril/Prentice Hall.

[66] Tribble, C. (1996). Writing. Oxford: Oxford University Press.

[67] Truscott, J. (1996). The Case Against Grammar Correction in L2 Writing Classes. Language Learning, 327-369.

[68] Tuzi, F. (2004). The Impact of E-Feedback on the Revisons of L2 Writers in an Academic Writing Course. Elsevier, 217-235.

[69] Urterl, M. G. (2008). Assessing Academic Performance between Traditional and Distance Education Course Formats. Educational Technology \& Society, 322-330.

[70] Ware, P. D., \& Warschauer, M. (2006). Electronic Peer Feedback and Second Language Writing. Cambridge: Cambridge University Press.

[71] Warschauer, M. (2007). Technology and Writing. Springer, 907-912.

[72] Wilcox, B. L., \& Wojnar, L. C. (2000). Best Practice Goes Online. International Reading Association, 1 19.

[73] Williams, J. G. (2003). Providing Feedback on ESL Students' Written Assigment. The Internet TESL Journal, 1-7. 


\section{AUTHOR'S BIOGRAPHY}

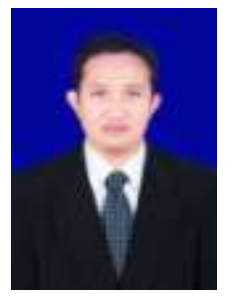

Wardani Dwi Wihastyanang, was born in Jombang, in 1985. He received the S.Pd degree in English Language Education Program from STKIP PGRI Jombang, Indonesia, in 2008, and the M.Pd. degrees in English Language and Literature Program from the Surabaya State University (UNESA) Surabaya, in 2010.

In 2010, he joined the English Language Education Department of STKIP PGRI Jombang, as a Lecturer. To be qualified lecturer, he pursued his higher education for Doctorate Program at State University of Malang (UM) in 2013 and will be graduated on 2018. His current research interests include Linguistics, English Language Teaching, Literary and Educational Technology.

Citation: Wardani Dwi Wihastyanang "The Impact of Electronic Feedback on Second Year English College Students' writing Quality " International Journal on Studies in English Language and Literature (IJSELL), vol 5, no. 12, 2017, pp. 56-67. doi:http://dx.doi.org/10.20431/2347-3134.0511006.

Copyright: (C) 2017 Authors. This is an open-access article distributed under the terms of the Creative Commons Attribution License, which permits unrestricted use, distribution, and reproduction in any medium, provided the original author and source are credited. 